> amount of grant money distributed by funding agencies from around 15 billion roubles (US $\$ 500$ million) a year to 25 billion roubles by 2018. The average size of grants awarded by the Russian Foundation for Basic Research, for example, currently some 350,000 roubles (US\$12,000) per year, will be "made comparable to Western grants", he wrote.

Researchers welcome more cash, of course, but the plan implies that the number of grants might actually go down, notes Konstantin Severinov, who runs independent groups at the Russian Academy of Sciences (RAS) institutes for molecular genetics and gene biology in Moscow, and Rutgers University in New Brunswick, New Jersey.

Putin also intends to break the long-standing dominance of the academy, which employs around 50,000 scientists at more than 400 research institutes. He plans to redistribute some of the RAS's budget - currently about 50 billion roubles per year - to give other institutions and universities more money, as a key part of a sweeping ten-year science plan that he has asked the academy to develop.

Last month, the RAS administration made a start by asking leading scientists at its institutes to compile lists of research results that they expect to produce by 2030, including cost estimates. "This is just not how science works," says Severinov. To him, the unrealistic request is typical of the stifling bureaucracy prevalent in the Russian science system. "There are undeniably some advances in how science is run in this country. Alas, there are lots of missed opportunities as well," he says.

Mikhail Gelfand, a Moscow-based bioinformatician who in December spoke to a 100,000 -strong crowd of anti-Putin protesters, believes that, under Putin, a "background of omnipresent bureaucracy and corruption" will continue to hamper any Russian science revival. "It would be naive to expect that science alone somehow could, miraculously, blossom in this atmosphere," he says. - SEE EDITORIAL P.245

\title{
Forecasters look back in time
}

\section{As the next IPCC assessment nears, scientists use palaeoclimatic data to hone their models.}

\section{BY JEFF TOLLEFSON}

I $\mathrm{t}$ is hard to imagine beaches in northern Greenland or driftwood washing up on islands of Canada's Arctic archipelago, but both were a reality some 6,000 years ago. "At least seasonally, those areas must have been ice-free," says Gavin Schmidt, a climate modeller at NASA's Goddard Institute for Space Studies in New York. The warming was caused primarily by cycles in Earth's orbit, not a spike in greenhouse-gas levels, but climate modellers are revisiting the long-gone era as they prepare to deliver their next global forecast.

The temperate mid-Holocene epoch is one of three episodes included in the World Climate Research Programme's Coupled Model Intercomparison Project, which will form the basis of next year's fifth assessment by the Intergovernmental Panel on Climate Change (IPCC). Simulating palaeoclimates is a challenge, but many scientists say they have enough data from sources such as marine-sediment cores, tree rings and cave deposits to evaluate various aspects of their models. "It's important to check the ability of our climate models to simulate a different climate, because our future world is also quite different from the present," says Masa Kageyama, a palaeoclimate modeller at the Pierre-Simon Laplace Institute near Paris.

Owing, in part, to past computational limitations, palaeoclimate simulations have never been systematically factored in to the IPCC modelling effort. With a July deadline for submitting papers approaching, members of the IPCC's physical-science working group gathered in Honolulu, Hawaii, for a pair of workshops, held over the past fortnight, to discuss palaeoclimate modelling and the range of other simulations on which their assessment depends. Scientists presented early results from the latest generation of climate models, which take into account factors such as the impact of land use and vegetation, as well as an increasingly sophisticated treatment of atmospheric physics and chemistry. The simulations explore the effects of a broad range of potential future greenhousegas concentrations, including an extreme case in which the amount of carbon dioxide rises to more than three times its current level.

Some wondered whether the increased complexity could add to the uncertainties of the new

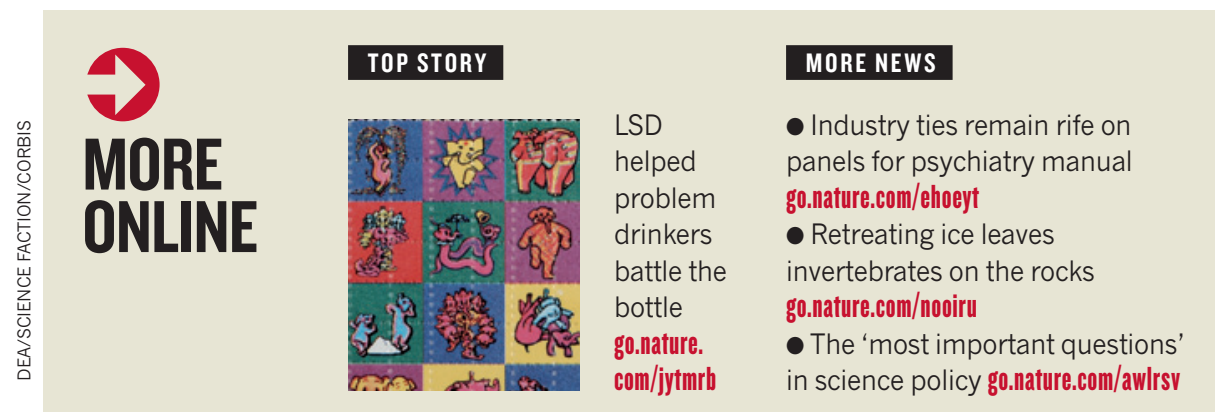

models and create a larger range of climate projections, but Jerry Meehl, a climate scientist at the National Center for Atmospheric Research in Boulder, Colorado, and one of the workshop organizers, says the spread of projections is "roughly the same" as that produced by the previous generation of models. Ron Stouffer, a climate researcher at the "It turns out National Oceanic and that land-use changes were as large a player as fossil-fuel emissions were." Atmospheric Administration's Geophysical Fluid Dynamics Laboratory in Princeton, New Jersey, says that his team's model has already delivered surprises on the increase in atmospheric carbon dioxide levels. "It turns out that land-use changes, right up to about 1950 or even 1970 , were as large a player as fossil-fuel emissions were," he says. "And even today they are not trivial."

More than 20 groups around the world are still processing and uploading modelling data onto a server network that will be accessible to everyone involved in the exercise. So far, more than 2 million files and a petabyte of data have been uploaded. Organizers expect that amount to triple, taking it to roughly 100 times that amassed during the last round of modelling for the IPCC's fourth assessment in 2007. The amount of data is creating new challenges in terms of information management, says Karl Taylor, who works with modellers on experiment design at Lawrence Livermore National Laboratory in Livermore, California. "We're seeing an awful lot of results," Taylor says, "but we're also up against deadlines, and everyone is a bit frantic." - 